\title{
Finding success by following your heart
}

\author{
Nancy Y. Ip is Vice President for Research and Graduate Studies, the Morningside Professor of Life Science, and \\ Director of the State Key Laboratory of Molecular Neuroscience at the Hong Kong University of Science and \\ Technology, Hong Kong, China. Her career in the field of neuroscience spans over three decades.
}

\author{
Nancy Y. Ip
}

\begin{abstract}
t was during my $\mathrm{PhD}$ studies at Harvard that I discovered my passion for neuroscience in the lab of Richard Zigmond. The field was at its infancy with so much to explore. Despite a slow start, my $\mathrm{PhD}$ years were very rewarding, with multiple first-author papers published in high quality journals, including Nature. On graduating, I was filled with excitement and determination to continue my contributions to the field. However, life had other plans. After a short postdoc, I took a year off to provide full-time care to my baby daughter and one-year-old son. This was a cherished time for me, and when I returned to the workforce I took a position in a biotech company that afforded a better work-life balance, which I felt was important for my young family. The work was enjoyable but I yearned to conduct neuroscience research again, to experience the deep satisfaction of contributing to the field.
\end{abstract}

Then, in a touch of serendipity, I learned about an exciting opportunity at Regeneron, a young biopharmaceutical company in New York. With its focus on exploratory fundamental research, it offered the potential to make a mark in the neuroscience field through cuttingedge science. I was struck by the dynamic and collaborative environment, and the shared enthusiasm for advancing the field that existed within the small team of scientists. Joining Regeneron as a staff scientist marked a turning point in my career. I was thrilled to be conducting basic neuroscience research again. My colleagues and I focused on understanding neurotrophic factors and their regenerative capabilities. Little was known of these proteins and we excitedly embraced the challenge of determining their biological functions. Regeneron offered the unique opportunity to contribute to successful translational outcomes through basic research, and my colleagues and I worked very hard to push the boundaries of the field. The strong camaraderie we developed sustained us during frustrating periods, while our shared goals pushed us to develop creative and innovative approaches. Our efforts led to significant discoveries that helped propel the field forward.

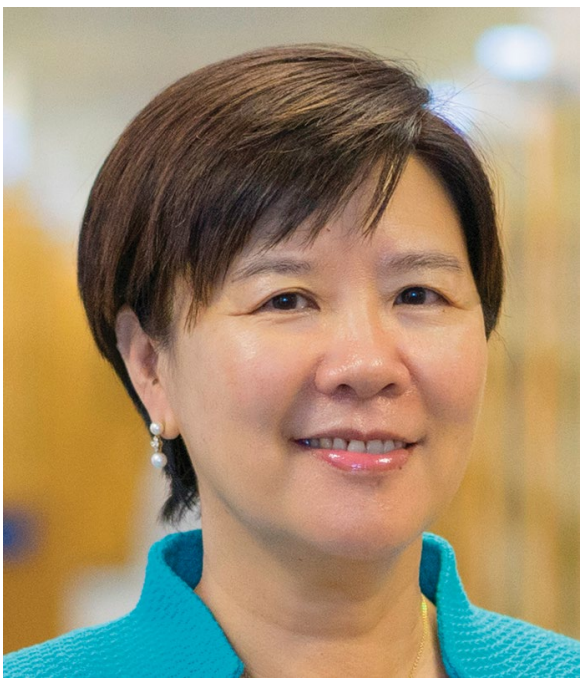

This inspiring and intellectually stimulating environment helped me thrive. Every success pushed me to work harder. But as other women scientists with a family, I had to find ways to balance my career and home life. Caring for my two young children was my priority, but I had an extremely demanding work schedule, which required long hours in the lab. I had to quickly become proficient at time management and multi-tasking. Juggling the roles of scientist and mother was not easy, and I was constantly struggling with whether to complete one more experiment before heading home. My passion for neuroscience and the love for my family helped me embrace these daily challenges. Within two years, I was promoted to senior staff scientist-the first woman in the company at the senior management level. I remained the only senior woman scientist during the company's early years, and was often the only woman present at high-level meetings. By letting my work speak for itself, I held my own among the other scientists. These experiences held me in good stead on numerous instances later in my career when I again found myself to be the only woman at high-level strategic meetings, or when leading large groups of colleagues comprised mostly of men.

Regeneron also played a major role in my professional development as a scientist. Of note is the mentorship I received from George Yancopoulos. An exceptionally talented scientist with boundless energy, he inspired me to fulfil my scientific aspirations. I learned how to be a good leader and how to motivate and inspire a team. His confidence in my abilities gave me the courage to take risks and push the boundaries of my research. It is not surprising that under his fearless leadership, Regeneron has emerged as one of the most successful biotech companies in the world.

In 1993, after four years at Regeneron, I decided to return to my home city of Hong Kong to start an academic career at the newly established Hong Kong University of Science and Technology (HKUST). Leaving a thriving career in industry for a position at an unknown university was both extremely daunting and exciting. This new chapter of my career brought fresh challenges. I had to build my research from scratch with limited funding. Attracting high-calibre $\mathrm{PhD}$ candidates and staff to a new and unranked university was also difficult, as was networking with peers since, back then, Hong Kong lacked a vibrant scientific community. As I worked through these obstacles, often drawing on my experiences at Regeneron, I realized the significant impact the company had on my professional development. During my time there, I learned the importance of following my passion in life: neuroscience research. By engaging in work that I loved, I was motivated to persevere regardless of the challenges, which led me to professional success. In the ensuing 25 years at HKUST, I continued to follow my heart, which, together with dedication and diligence, has been instrumental in my research accomplishments and career progression.

\section{Nancy Y. Ip}

Division of Life Science, State Key Laboratory of Molecular Neuroscience, The Hong Kong University of Science and Technology, Hong Kong, China. e-mail:boip@ust.hk

Published online: 28 August 2018 https://doi.org/10.1038/s41556-018-0159-3

Competing interests

The author declares no competing interests. 